\title{
Tutkijat ja aseistariisunta
}

"Aikakautemme suuriin paradokseihin kuuluu se, että samalla, kun tieteellis-tekninen kehitys on tuonut eteemme potentiaaliset keinot aikamme polttavien ongelmien: nälänhädän, köyhyyden, sairauksien ja lukutaidottomuuden poistamiseen, valtaosa tieteellisistä resursseista on suunnattu noiden ongelmien ratkaisemisen kannalta vastakkaisiin tehtäviin: entistä tehokkaampien joukkotuhoaseiden ja taistelumenetelmien kehittämiseen. Vuosittain asevarusteluun käytetään nykyään noin 300 miljardia dollaria, joka on noin 6 prosenttia maailman kokonaistuotteesta. Samanaikaisesti viralliseen kehitysapuun käytetään maailman kokonaistuotteesta selvästi alle 0.3 prosenttia." Näin totesi Tutkijaliiton liittokokous marraskuussa 1976.

Tällä hetkellä on kamppailu rauhan puolesta sotaa ja sodanvoimia vastaan entistä ajankohtaisempaa. Tieteen ja kulttuurin voimien osallistuminen tähän kamppailuun on yhä tärkeämpää.

ETYK:in jälkeen seuraava etappi liennytyksessä voi olla vain varustelukilvan lakkauttaminen ja aseistariisunnan toteuttamisen aloittaminen. Koko maailman ja koko ihmiskunnan kannalta tärkeintä tällä hetkellä on rauhan, turvallisuuden ja yhteistyön ehtojen vahvistaminen. Se merkitsee ensi sijassa liennytyksen saavutusten tekemistä peruuttamattomiksi, liennytyksen asteen syventämistä, liennytyksen ulottamista myös muihin maanosiin kuin Eurooppaan. Saavutettuja edistysaskeleita vastaan on ETYK:in jälkeen noussut synkkiä voimia, jotka ajoittain näyttävät yllättävästikin vahvistuneen - tai ainakin käyneen entistä hyökkäävämmiksi ja meluisammiksi. Liennytyksen logiikan mukaista ei ole SALT:in tai Geneven neuvottelujen paikoillaanpolkeminen. Liennytyksen logiikan mukaista ei ole läntisessä lehdistössä esiinnostettu epämääräinen ja vihjaileva puhe "neuvostouhasta". Liennytyksen logiikan mukaista ei ole pyrkimys kylmän sodan kaltaisen maailmantilanteen palauttamiseen. Tällaisia tendensseja on kuitenkin ilmiselvästi näkyvissä talouden, politiikan ja ideologian alalla sekä yhtä hyvin myös sotilaallisella sektorilla.

Kenen etujen mukaista on kiihdyttää kilpavarustelua ja estää aseistariisunnan toteuttaminen? Se ei voi olla niiden maiden etu, jotka keskittävät voimavaransa sosialismin ja kommunismin rakentamiseen. Se ei voi olla myöskään niiden maiden etujen mukaista, jotka vasta ovat vapautuneet siirtomaaorjuutuksesta ja muodostuneet kansakunniksi. Se ei voi olla y hd e n kää n kansan etu; kaikki kan sat haluavat rauhaa. Poliittisen jännityksen kiristämisen, sodanvaaran ja voimakeinoilla uhkaamisen lähteet ovat nyt kuten ennenkin monopolipääomassa ja imperialismissa. Sen osoittaa vastaansanomattomalla tavalla koko tämän vuosisadan historiallinen kokemus. Aggressiivisuus, taipumus sotaan ja talouden militarisointi eivät ole mitään ulkokohtaisia lisäkkeitä monopolikapitalismissa. Ne ovat imperialismin s i s ä i s i ä lainmukaisuuksia.

Kaikkein kärkevimmän ilmauksensa imperialismin lainmukaisesti sotai- 
nen luonne saa ns. sotilaallis-teollisen kompleksin muodostumisessa, kehityksessä ja kasvussa. Suomen kaltaisessa pienessä kapitalistisessa maassa, jonka virallinen ulkopolitiikka on useimpiin vastaaviin maihin nähden poikkeava, ei sotilaallis-teollisen kompleksin olemassaolo näy siten kuin suurissa kapitalistisissa maissa. Näissä maissa sotilaallis-teollinen kompleksi - monopolien ja sotilasjohdon yhteenkietoutuma - on todellinen "valtio valtiossa", se muodostaa taloudellisen ja poliittisen tapahtumisen keskipisteen. Varustelumonopolit ovat säännönmukaisesti suurimpia monopoleja; ja vastaavasti suurimmat monopolit ovat suuremmassa tai pienemmässä määrin kietoutuneet varusteluun. Varusteluteollisuudessa voittosuhde on edullisin, valtio takaa tilauskannan säilymisen ja kasvun, ja varustelumonopoleja pyritään käyttämään taloudellisten kriisien ratkaisun välineenä. Oli nousu- tai laskusuhdanne, oli sota tai rauha, varustelumonopolit ovat aina kuivilla. Sotilaallis-teollinen kompleksi vaikuttaa sisä- ja talouspolitiikkaan ratkaisevalla tavalla, se määrää usein myös ulkopolitiikan suunnan. Se toimii parlamenteissa ja niiden ulkopuolella, hallituksissa tai niiden ohi. Juuri sotilaallis-teollisen kompleksin kohdalla käy kaikkein havainnollisimmin ilmi porvarillisen demokratian rappeutuminen, kapitalismin loismainen ja mätänevä luonne. Kun sotilaallis-teollinen kompleksi joutuu kulissien takaa päivänvaloon, tapahtuu se ennen kaikkea skandaalien muodossa: Lockheed, ITT, Dassault, Hispano-Suiza, Krupp jne.

YK:n pääsihteerin raportin mukaan maailmassa on noin. 50 miljoonaa ihmistä, jotka suoraan tai välillisesti ovat tekemisissä sotilaallisten toimintojen kanssa. Yhdenmukaisesti talouden militarisoimisen kanssa tapahtuu myös tieteen ja tutkimuksen militarisointi. On arvioitu, että sotilaalliseen tutkimustyöhön osallistuu maailmassa 400000 tutkijaa. YK:n julkaisemien tietojen mukaan käytettiin maailmassa 1970-luvun alussa lääketieteelliseen tutkimukseen 4 miljardia dollaria vuodessa, mutta varustelututkimukseen peräti 25 miljardia dollaria. Konkreettisempi esimerkki: vuosina 1968-1975 Yhdysvallat käytti noin 129 miljoonaa dollaria US AIM-7F Sparrow ohjustyypin kehittelyyn edeltäjästään US AIM$7 \mathrm{E}$ ohjuksesta; samana ajanjaksona Maailman Terveysjärjestö WHO käytti menestykselliseen kampanjaansa isorokon hävittämiseksi 83 miljoonaa dollaria. Tämä ei ole ihmiskunnan etujen mukaista, se ei ole myöskään tutkijoiden itsensä edun mukaista.

Kaikkien tiedossa on, että Suomessa harjoitetaan suhteellisen pienessä määrin sotilaallista tutkimusta. Mutta kaikkien tiedossa ei ole, että tätä tutkimusta joka tapauksessa harjoitetaan ja ettei se ole aivan vähäistä. Läpi 1970-luvun sotilaalliseen tutkimukseen käytettyjen määrärahojen osuus on pysynyt yli $4 \%$ tasolla. Vuonna 1975 sotilaalliseen tutkimukseen käytettiin selvästi enemmän varoja kuin esim. koulutusta ja sosiaaliturvaa koskevaan tutkimukseen. Huomattava osa Suomen pienestä tutkimuspotentiaalista - erityisesti teknisissä tieteissä ja yhteiskuntatieteissä - 
on kiinnitetty sotilaalliseen tutkimukseen. Maanpuolustuksen tieteellisen neuvottelukunnan välityksellä useita tutkijoita ja tutkimuslaitoksia, jopa korkeakouluja on kiinnitetty sotilaallista tutkimusta palveleviin päämääriin. Lisäksi on syytä pitää mielessä, että maassamme harjoitetaan sotilaallista tutkimusta myös USA:n puolustusministeriön rahoituksella.

Marraskuun liittokokouksessaan Tutkijaliitto yhtyi Moskovassa heinäkuussa 1975 pidetyn laajan kansainvälisen tiedemiestapaamisen julkilausumaan. Siinä todettiin: "Tiedetyöntekijöille ei voi olla yhdentekevää, mihin heidän työtään käytetään. Enemmän kuin koskaan aiemmin tiedetyöntekijöiden moraalinen velvollisuus, heidän vastuunsa ihmiskunnalle, edellyttää, että he pyrkivät estämään tieteen käytön tuhoamistarkoituksiin. (...) Yhteisin ponnistuksin tiedetyöntekijät voivat tehdä paljon estääkseen uuden kylmän sodan aikakauden, edistääkseen jännityksen lievenemistä sekä luottamuksen ja yhteistyön kehittymistä kaikkien valtioiden välisissä suhteissa, auttaakseen varustelukilvan pysäyttämisessä sekä täydellisen ja yleisen aseistariisunnan aikaansaamisessa."

Rauhan rintama on maailman laajin rintama. Se on laajempi kuin sosialismin rintama, se on jopa laajempi kuin demokratian ja yhteiskunnallisen edistyksen rintama. Rauhanrintama on objekti ivise sti maailman laajin rintama, mutta onko se sitä myös s u bje kti i vise sti? Joskus tuntuu siltä, että niin paljon ja niin vilpittömiä ihmisiä kuin rauhan kannalla onkin, ovat nämä ihmiset sittenkin pikemmin rauhantyön passiivisia objekteja kuin aktiivisia subjekteja. Porvarillisen yhteiskunnan logiikka, porvarillisen yhteiskunnan arkielämä kasvattaa jo spontaanisti sellaista ajattelua, että kysymys sodasta ja rauhasta on ikään kuin ulkoinen "kohtalo", johon ihmiset itse, joukot, eivät pysty vaikuttamaan. Tätä ajattelua taantumusvoimat pyrkivät tehokkaasti pitämään yllä. Aktiivisimmat rauhanvastustajat toistavat jatkuvasti väitettä, että rauhan turvaaminen on h a lli t u st e n eikä ka n s a n jouk k o je n asia. O. W. Kuusinen kirjoitti tästä asiasta terävästi 1951: "Kummallinen logiikka noilla rauhanvastustajilla: sota on heistä aina 'yhteinen asia', olipa se sitten vaikka kuinka epäoikeudenmukainen, mutta silloin kun kansan yhteisenä asiana on sodan välttäminen, rauhan turvaaminen, silloin ei kansa saisi sekaantua asiaan!" Rauhan turvaaminen on tietenkin myös hallitusten asia, mutta ei yksinomaan niiden. Rauhan turvaaminen on samalla ja ennen kaikkea joukkojen ja joukkoliikkeiden asia.

Mitä laajemmin rauhanaate on valloittanut joukot, mitä laajemmin joukot toimivat rauhan liikevoimana, sitä varmemmin rauha säilyy ja syvenee.

Tutkijoiden osallistuminen rauhanliikkeeseen on jo pitkään ollut tieteen ja edistyksen liiton, tutkijoiden ja joukkojen yhteistoiminnan kauneimpia hedelmiä. Ajatelkaamme esim. Einsteinin, Bernalin, Joliot-Curien, Paulingin ja Russellin roolia rauhanliikkeessä. Tai ensimmäistä Tukholman vetoomusta 1950-luvun alussa, jossa tutkijoiden panos oli hyvin näkyvä. Tai 
tiedemiesten omaa Pugwash-liikettä kilpavarustelun lakkauttamiseksi. Näihin perinteisiin vetoaminen on erityisen ajankohtaista juuri nyt. Tutkijoiden tehtäväksi tulee - edustavat he mitä tieteenalaa tahansa - aktiivinen osallistuminen rauhantyöhön. Se merkitsee tässä vaiheessa kamppailua kilpavarustelun pysäyttämiseksi ja yleisen $\mathrm{ja}$ täydellisen aseistariisunnan aloittamiseksi. Tämän tehtävän ei pitäisi olla mikään ulkokohtainen pakko, vaan sisältä käsin kasvava velvollisuus ja vakaumus. Näitä kysymyksiä on tutkittava, niistä on puhuttava ja kirjoitettava, ne on otettava esille tutkijajärjestöissä ja muualla, kaikkialla missä joukot ovat. Tutkijoiden ja joukkojen liitto rauhantyössä on luonteeltaan kaksipuolinen: tutkijat eivät ainoastaan vakuuta joukkoja rauhantyön merkityksestä, vaan myös joukot vakuuttavat ja kasvattavat tutkijoita. Tällä hetkellä asian laita rauhanliikkeen järjestöissä on sellainen, että joukoilla on tutkijoille 1 i i a n k i n paljon annettavaa! Tutkijat eivät vielä ole osallistuneet meillä siinä määrin rauhanliikkeeseen kuin pitäisi.

Maamme kulttuurikeskustelussa on viime aikoina ollut esillä monia teemoja. Rauhankysymys tulisi nostaa niiden joukkoon. Mikään erillinen kysymys se ei ole. Viime viikkoina on keskusteltu esim. humanismista. Täysin selvää on, että meidän aikanamme humanismi, joka ei pidä sisällään aktiivista rauhantyötä, ei ole mitään humanismia.

\section{Tässä numerossa}

Petroskoilainen tri Eino $\mathrm{K}$ a $\mathbf{r h ~ u}$ on tehnyt mittavan työn Suomen kirjallisuus- ja kulttuurihistorian parissa. Hänen laajasta tuotannostaan on meillä ilmestynyt "Suomen 1900-luvun alun kirjallisuus", ja näinä päivinä ilmestyy "Dostojevski ja suomalainen kirjallisuus". Karhu on lisäksi kirjoittanut suuren joukon esseitä ja artikkeleita, joista monet ovat tulleet suomalaisille lukijoille tutuiksi neuvostokarjalaisesta "Punalippu" -julkaisusta. Tässä numerossa julkaisemme Karhun kirjoituksen A. I. Arwidssonista ja hänen suhteestaan kansalliseen herätykseen. Tämä artikkeli ei ole vähiten mielenkiintoinen siitä syystä, että viime vuosina Suomen kaikkein äärioikeistolaisimmat ideologit ovat pyrkineet ottamaan Arwidssonin omaksi tulkikseen, nationalismin ja taantumuksen pasuunaksi. Karhun artikkelia ei ole aikaisemmin julkaistu muualla, vaan se on ensi kertaa luettavissa "Tieteen ja edistyksen" palstoilta.

Tutkijaliitto järjesti 12.3. yhteiskuntatieteiden historiaa käsitelleen seminaarin. Tässä tilaisuudessa valt.tri Risto $A l$ a p u ro piti marxilaisen yhteiskuntatutkimuksen historiasta Suomessa esitelmän, joka herätti vilkasta keskustelua ja mielipiteidenvaihtoa. Julkaisemme Alapuron esitelmän ja joitakin puheenvuoroja sen keskusteluun haastavasta tematiikasta.

ETYK:istä ja ETYK:in vierestä on viime kuukausina puhuttu paljon lehdissä ja muissa joukkotiedotusvälineissä. Porvarillis-taantumuksellisen 
lehdistön kanta ETYK:iin on niin kaksimielinen kuin ajatella saattaa: toisaalta väheksytään ETYK:in merkitystä jonkinlaisena "diplomaattisena karnevaalina", välistä taas liitetään siihen demagogiaa, jolla ei ole mitään tekemistä turvakokouksen luonteen eikä päätösten kanssa. Keskustelu ETYK:istä on näinä viikkoina entistä ajankohtaisempaa, nyt kun Belgradin seurantakokous on lähestymässä. Julkaisemme OTL Lauri $\mathrm{H}$ a n n ik a i se n kirjoituksen "ETYK:in päätösasiakirja ja kansainvälinen oikeus".

Luonnontieteen historiasta ei maassamme ole paljoa kirjoitettu. Kuitenkin aiheen tuntemus on tärkeää sekä yleensä tieteen historian että erityisesti luonnontieteen nykyisen teoriakokonaisuuden ymmärtämisen kannalta. Julkaisemme länsisaksalaisen Michael Woll f i n artikkelin Newtonin mekaniikan taustasta. Newtonin kuolemasta tuli tänä vuonna kuluneeksi 250 vuotta.

Antero Ti u s a n e n on saanut valmiiksi tähän asti tärkeimmän käännöstyönsä, "Pääoman" kolmannen osan suomennoksen. Haastattelemme Tiusasta tämän suurtyön vaiheilta kosketellen samalla marxilaisen tekstin käännösongelmia yleensä sekä käännöksen ja tutkimuksen välisiä suhteita. 